\section{Fulminant lærebog i psykiatri}

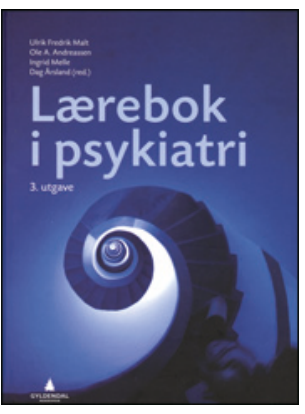

Ulrik Frederik Malt, Ole A. Andreassen, Ingrid Melle et al, red.

Lærebok i psykiatri

3. utg. 1086 s, tab, ill. Oslo: Gyldendal

Akademisk, 2012. Pris NOK 925

ISBN 978-82-05-39739-2

Dette er tredje udgave af Laerebok i psykiatri, men både redaktion, forfatterpanel og indhold har gennemgået en omfattende forandring siden den sidste udgave blev udgivet i 2003. Målgruppen er først og fremmest medicin- og psykologistuderende, almen praktiserende læger og psykologer, der skal beskæftige sig med psykiatri på specialistniveau. Bogen er opbygget af 33 kapitler, som dækker et bredt spektrum inden for psykiatrien, og der er medtaget meget stof $\mathrm{i}$ hvert kapitel. For at tydeliggøre at ikke alt forventes at være pensum for studenterne er dele af stoffet trykt med mindre skrift, men selv det der er trykt med stor skrift er ganske omfattende og udtryk for et højt fagligt niveau og flotte ambitiøse mål for hvad studenterne skal kunne.

Bogen indledes med en gode række kapitler, som ikke er sygdomsspecifikke. Her skal særligt fremhæves kapitlerne om psykiatriens historie, om kunnskabsbasert psykiatri og om molekylærgenetik.

Alle de kliniske kapitler indeholder gode kliniske vignetter, der på pædagogisk vis illustrerer sygdomstilfældene. Der er medtaget kapitler om ADHD og autismespektrumforstyrrelser i erkendelse af at disse lidelser også spiller en rolle i voksenalderen. De diagnostiske kriterier er omtalt i hvert kapitel, og skalaer til bedømmelse af sværhedsgrad af psykopatologi er gennemgået $i$ alle relevante tilfælde. En række illustrationer, tabeller og figurer bidrager til at formidle budskabet klart og overskueligt.

Bogen afsluttes med en række ikke sygdomsspecifikke kapitler, der alle er velvalgte og inspirerende at læse.

Redaktionen har sikret sig at professionelle med absolut spidskompetence er inddraget som forfattere til hver deres kapitler, og bogen opnår derved stor autoritet.

Teksten er velskrevet og lettilgængelig. Sproget er homogent, og man mærker ikke at forskellige forfattere har været involveret. Bogen må stærkt anbefales til medicinstuderende, som ved læsning opnår en meget fyldestgørende introduktion til faget. Alment praktiserende læger, læger under specialistuddannelse i psykiatri, speciallæger i psykiatri og også professorer i psykiatri (som anmelderen) kan lære meget ved at læse den.

Dele af indholdet kan også anvendes af tværfagligt personale, patienter og pårørende.

\section{Merete Nordentoft}

Psykiatrisk Center København

Det Sundhedsvidenskabelige Fakultet

Københavns Universitet

\section{Å balansere med kropp og sjel}

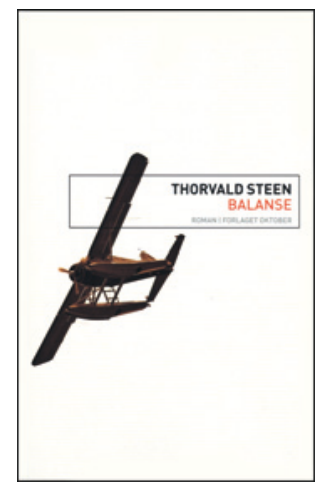

Thorvald Steen

Balanse

201 s. Oslo: Forlaget Oktober, 2012

Pris NOK 369

ISBN 978-82-495-1032-0

Balanse er en roman om livet sett gjennom øynene til en syk mann på pleiehjem. Fortelleren, hvis navn vi aldri får vite, lider av en muskelsykdom. Han er den yngste på pleiehjemmet. Dagene går med til å skrive på et uendelig brev til sin eneste datter, se på utsikten fra vinduet og å drømme forvirret. Han både forakter og blir glad i sine medpasienter. Legebesøk skildres fornøyelig sarkastisk, og avdelingens sykepleier er helsevesenets eneste lysstråle. Nesten.

Gjennom romanen får vi et sideblikk på eldreomsorgen, der personlige møter og menneskelige kvaliteter er det eneste som veier opp for en ellers neglisjert del av systemet. Pleiehjemmets hverdag er monoton, omsorgen opprettholdes så vidt - takket være en dedikert og overarbeidet sykepleier. Legen er resignert og godkjenner altfor små budsjetter uten å mukke. Men i de triste omgivelsene finnes også livlige medpasienter, nære møter, gamle minner, vakre solnedganger og uventede og litt rare hendelser.

Språket er enkelt og vakkert. Kroppen brukes stadig som metafor på tilstander og følelser, og slik sett er boken nært knyttet til faget vårt. Hovedpersonen er smertelig klar over kroppen sin, den som etter hvert begrenser ham mer og mer, men som også er hans tilgang til verden. Nysgjerrigheten gir ham livslyst: «Kroppen nyter eller kjenner smerten, og bearbeider den med hodet og hjernen. Hjernen og øynene er intakte. Å registrere det jeg ser rundt meg, gir livet mening.»

Kapitlene veksler mellom det som skjer på pleiehjemmet, minner om datteren og nattens kaotiske drømmer. Selv om det sjelden skjer noe dramatisk, er alle de små nyansene og hverdagslige detaljene skildret så nært og vibrerende at de blir viktige og store i seg selv.

Balanse er en nær og fin bok. Hovedpersonens handlinger er ikke alltid like forståelige, men slik blir han kanskje bare mer menneskelig. Beskrivelsene av legebesøk og helsevesen kan leses som en oppfordring til å ta oss mer tid, være mer personlige og våge å satse på livslysten hos eldre mennesker. Men først og fremst er dette en fortelling om et liv, fortalt med en lavmælt og ofte humoristisk stemme som viser oss hvordan alle små øyeblikk og bruddstykker er intense og viktige i seg selv.

\section{Ane Brandtzæg Næss}

Det medisinske fakultet

Universitetet i Oslo 